\title{
Biochemical examination of non-transgenic and transgenic soybean plants under drought stress conditions
}

\author{
C.G. GONÇALVES ${ }^{1 *}$, A.C. SILVA Jr. ${ }^{2}$ L.R. ALVES ${ }^{3}$, M.R.R. PEREIRA ${ }^{4}$, P.L. GRATÃO ${ }^{3}$, \\ and D. MARTINS ${ }^{2}$ \\ Department of Crop, Soil and Environmental Sciences, Auburn University, 36849 Auburn, AL, USA ${ }^{1}$ \\ Depto. de Produção Vegetal ${ }^{2}$ and Depto. de Biologia Aplicada à Agropecuária ${ }^{3}, F C A V$, UNESP \\ 14884-900 Jaboticabal, SP, Brazil \\ Faculdade de Tecnologia de Capão Bonito, 18304-755 Capão Bonito, SP, Brazil ${ }^{4}$
}

\begin{abstract}
Drought is one of the major environmental stresses limiting crop production worldwide because both the duration and the severity of the stress are critical. Plants display a variety of physiological and biochemical stress responses towards prevailing drought stress thus making it a complex phenomenon. To address the modulation of stress responses, we used Glycine max cv. MG/BR 46 Conquista (non-transgenic) and cv. BRS Valiosa (transgenic) to analyze the effects of progressive drought stress during two stages of soybean development (V2 and V4) on physiological and biochemical parameters. Three minimum soil water potentials ( $\Psi$ s) were established: $-0.03 \mathrm{MPa}$ (well-watered), $-0.07 \mathrm{MPa}$ (a moderate stress), and $-0.5 \mathrm{MPa}$ (a severe stress). Gas-exchange measurements, lipid peroxidation, $\mathrm{H}_{2} \mathrm{O}_{2}$ and proline content, and antioxidant enzyme activities were analyzed in the leaves of both cultivars in the different water management levels. The results show a decrease in plant growth and gas-exchange parameters in both genotypes during progressive drought stress; the effects were more pronounced in MG/BR 46 Conquista. Proline content was less affected in BRS Valiosa. Malondialdehyde and $\mathrm{H}_{2} \mathrm{O}_{2}$ content increased during the drought stress but less in transgenic plants. Superoxide dismutase, catalase, and ascorbate peroxidase activities increased in BRS Valiosa at the V4 stage, whereas MG/B R 46 Conquista did not overcome stress conditions at this period. The overall results suggest that BRS Valiosa (transgenic) soybean cultivar exhibited later stress responses, which could enhance its survival during long periods of water deficit.
\end{abstract}

Additional key words: ascorbate peroxidase, catalase, Glycine max, oxidative stress, superoxide dismutase, water managements.

\section{Introduction}

Soybean (Glycine max) cultivars are important protein sources for humans and animals. However, drought is the most limiting abiotic stress causing losses in soybean production (Ashraf 2010, Balardin et al. 2011, Juenger 2013, Silva et al. 2013, Hu and Xiong 2014).

Soybean requires a high soil water content due to its low water use efficiency; therefore, this crop is sensitive to drought stress (Yang et al. 2003). Due to climate changes in the last few decades, both the frequency and the severity of drought events are critical to soybean development. Drought stress caused by an imbalance between water uptake and transpiration leads to a disruption of physiological and biochemical processes at cellular and molecular levels (Ashraf and Harris 2013, Afzal et al. 2014). Cell division, elongation, and differentiation are negatively affected by water stress, which results in a decreased plant growth and development (Cabuslay et al. 2002, Shao et al. 2008). Moreover, drought during the reproductive stage is the main cause for grain yield reduction (Meckel et al. 1984, Demirtas et al. 2010, $\mathrm{Hu}$ and Xiong 2014).

Under normal growth conditions, the production of reactive oxygen species (ROS) occurs in cells; however, their accumulation during adverse environmental

Submitted 9 February 2018, last revision 6 August 2018, accepted 8 August 2018.

Abbreviations: APX - ascorbate peroxidase; CAT - catalase; EDTA - ethylenediaminetetraacetic acid; MDA - malondialdehyde; PVPP - polyvinylpyrrolidone; ROS - reactive oxygen species; SOD - superoxide dismutase; TCA - trichloroacetic acid; $\Psi$ s - soil water potential.

Acknowledgement: We thank the Coordenação de Aperfeiçoamento de Pessoal de Nível Superior (CAPES) for a scholarship grant.

* Corresponding author; fax: (+1) 334475 0660, e-mail: goncalvescg.agro@hotmail.com 
conditions can disrupt cellular homeostasis and cause oxidative damage to proteins and DNA, and lipid peroxidation, which in turn causes a severe damage to cell membranes (Demidchik 2015, Martinez et al. 2016, Choudhury et al. 2017). However, ROS-detoxification mechanisms include some key enzymes, such as superoxide dismutase (SOD, EC 1.15.1.1), ascorbate peroxidase (APX, EC 1.11.1.11), and catalase (CAT, 1.11.1.6) (Hippler et al. 2015, Silva et al. 2016, Alves et al. 2017), as well as non-enzymatic compounds such as proline, flavonoids, and carotenoids (Ahmad et al. 2010, Fang and Xiong 2015). Proline accumulation is one of the most common responses to water deficit as it plays a role as an osmoprotectant and a compatible solute (Madani et al. 2010, Sharma et al. 2012, Sarkar et al. 2015, Li et al. 2016, Mwadzingeni et al. 2016).

Drought stress is a huge challenge in agriculture; therefore, breeding cultivars that exhibit a satisfactory yield during drought stress conditions becomes necessary. Moreover, some transgenic plants may exhibit better abilities of ROS scavenging, which could be useful in overcoming drought stress (Farooq et al. 2009). Although the literature does not report the commercial transgenic cultivar BRS Valiosa (in which gene for resistance to herbicide glyphosate was inserted) as

\section{Materials and methods}

Soybean (Glycine max L.) seeds of non-transgenic MG/BR 46 Conquista (MG/BR) and commercial transgenic cultivar BRS Valiosa (BRS) cultivars obtained from the EMBRAPA-Soya germplasm bank, were sown at a $2-3 \mathrm{~cm}$ depth in plastic pots filled with $3 \mathrm{~kg}$ of dry soil.

Before sowing, the soil was air-dried to a constant moisture of $3 \%$. To obtain a water retention curve, the Richards pressure plate was used (Klar et al. 1966, Klar 1984). From the results of the retention curve (Fig. 1 Suppl.), three minimum soil water potentials ( $\Psi \mathrm{s})$ were established: $-0.03,-0.07$, and $-0.50 \mathrm{MPa}$, which reflect well-watered, moderate drought, and severe drought stress conditions. When the soil reached the water potential defined for each treatment, water was added to reach the maximum $\Psi$ s of $-0.01 \mathrm{MPa}$.

Pots were irrigated every day to maintain a $100 \%$ field capacity to ensure seed germination and seedling development. Plants were submitted to a drought stress for $10 \mathrm{~d}$ during the $\mathrm{V} 2$ vegetative growth stage (first open trefoil leaves) and during the V4 vegetative growth stage (third open trefoil leaves) (Fehr and Caviness 1977). Drought treatments were initiated by withholding water while the control plants remained well watered (100\% field capacity) during the period of the experiment. The treatment groups were exposed to the following different Is: -0.03 , -0.07 , and $-0.50 \mathrm{MPa}$. Water content in the pots was controlled by means of weighing. The pots were kept in a greenhouse with a temperature of $24 \pm 7{ }^{\circ} \mathrm{C}$, a relative humidity between 44.6 and $83.8 \%$, and a 12 -h drought tolerant, we have observed that this cultivar seems to be less affected by drought stress when compared to its wild type (non-transgenic cultivar MG/BR 46 Conquista). Although both cultivars have similar growth traits and genetic characteristics (Tsumanuma et al. 2010), the insertion of the gene that confers tolerance to the glyphosate may have activated target protein genes induced by drought stress. This higher drought stress tolerance of BRS Valiosa RR was observed in the first weeks of plant development (Gonçalves et al. 2017). Information regarding the differences among soybeans cultivars is essential in the search for more drought tolerant plants.

We investigated the possibility to improve drought tolerance, particularly considering antioxidant metabolism and its influence on water-use efficiency and yield in plants under drought stress (Farroq et al. 2009, Darmanti et al. 2016, Khakdan et al. 2016, Silva et al. 2016, Xing et al. 2016). This paper aimed to examine the growth parameters, lipid peroxidation, $\mathrm{H}_{2} \mathrm{O}_{2}$ content, proline, and enzymatic antioxidants in G/BR46 Conquista (non-transgenic) and BRS Valiosa RR (transgenic) soybean cultivars in response to different soil water content in two stages of vegetative development.

photoperiod. Samples of the leaves were harvested, rinsed, and immediately immersed in liquid $\mathrm{N}_{2}$ and stored at $-80{ }^{\circ} \mathrm{C}$ for further analyses.

After $10 \mathrm{~d}$, one plant was used for the assessments of height, stem diameter, and shoot dry mass. The plant height was measured from the soil level to the point of insertion of the apical bud. The stem diameter was measured $3 \mathrm{~cm}$ from the ground level using a digital caliper. The samples of leaves were kept in paper bags and dried in a drying oven $\left(60^{\circ} \mathrm{C}\right)$ to a constant mass.

Stomatal conductance $\left(\mathrm{g}_{\mathrm{s}}\right)$ was measured in a pair of completely expanded leaves from an intermediate height of the plant between 9 and 11 a.m. and cloud cover between 15 and $25 \%$ with a leaf porometer ( $S C-1$, Decagon Devices, USA.

Lipid peroxidation was assessed by determination of the content of thiobarbituric acid reactive substances, as described by Heath and Packer (1968). In a chilled mortar with a pestle, fresh leaves were ground with $20 \%(\mathrm{~m} / \mathrm{v})$ polyvinylpyrrolidone (PVPP) and $0.1 \%(\mathrm{~m} / \mathrm{v})$ trichloroacetic acid (TCA). After centrifugation at $11000 \mathrm{~g}$ for $10 \mathrm{~min}$, the supernatant was added to a solution of $5 \%$ $(\mathrm{m} / \mathrm{v})$ thiobarbituric acid and $20 \%(\mathrm{~m} / \mathrm{v})$ TCA and incubated in a water bath at $95{ }^{\circ} \mathrm{C}$ for $30 \mathrm{~min}$. The reaction was stopped in an ice bath for $10 \mathrm{~min}$ and the mixture was centrifuged at $11000 \mathrm{~g}$ for $10 \mathrm{~min}$. The content of malondialdehyde (MDA) equivalents was determined spectrophotometrically (S60 Biochrom, Cambridge, UK) between 535 and $600 \mathrm{~nm}$; the data were calculated using a coefficient of absorbance of 


\section{$1.55 \times 10^{-5} \mathrm{M}^{-1} \mathrm{~cm}^{-1}$ (Alves et al. 2017).}

Hydrogen peroxide content was measured using the method of Alexieva et al. (2001). Fresh leaves were homogenized in $0.1 \%(\mathrm{~m} / \mathrm{v})$ TCA and centrifuged at $10000 \mathrm{~g}$ for $10 \mathrm{~min}$. The supernatant was added to a 100 $\mathrm{mM}$ potassium phosphate buffer $(\mathrm{pH} 7.50)$ and $1 \mathrm{M}$ potassium iodide. This solution was incubated on ice for $60 \mathrm{~min}$, and then absorbance was read at $390 \mathrm{~nm}$. The $\mathrm{H}_{2} \mathrm{O}_{2}$ content was determined using an $\mathrm{H}_{2} \mathrm{O}_{2}$ concentration curve.

Proline content was measured as defined by Bates et al. (1973). Leaf samples were homogenized in $3 \%(\mathrm{~m} / \mathrm{v})$ sulphosalicylic acid. The filtrate was let react with $1 \mathrm{~cm}^{3}$ of ninhydrin acid and $1 \mathrm{~cm}^{3}$ of glacial acetic acid in a boiling water for $1 \mathrm{~h}$. Toluene $\left(4 \mathrm{~cm}^{3}\right)$ was added to the mixture, and absorbance was measured at $520 \mathrm{~nm}$ and calculated according to a proline standard.

Protein content was evaluated following the method of Bradford (1976) using bovine serum albumin as a standard. For determination of enzyme activities, fresh leaf tissue was homogenized in a chilled mortar with a pestle using an extraction buffer containing $100 \mathrm{mM}$ potassium phosphate buffer ( $\mathrm{pH} 7.5), 1 \mathrm{mM}$ ethylenediaminetetraacetic acid (EDTA), $3 \mathrm{mM}$ DL-dithiothreitol, and $5 \%(\mathrm{~m} / \mathrm{v})$ PVPP in a 3:1 ratio (Boaretto et al. 2014). The homogenate was centrifuged at $10000 \mathrm{~g}$ for $30 \mathrm{~min}$, and the supernatant was stored at $-80{ }^{\circ} \mathrm{C}$ for further determinations of SOD, CAT, and APX activities.

The SOD acitivity was measured according to

\section{Results and discussion}

Drought stress is one of the main causes of loss in crop production. Therefore, it is necessary to study strategies to avoid damage to plant growth and productivity. Thus, selecting cultivars that are better suited to overcome environmental adversities may be an interesting alternative. In this study, we observed that MG/BR and BRS exhibited significantly lower plant heights under a moderate drought stress $(-0.07 \mathrm{MPa})$ in both phenological stages (V2 and V4) compared to the controls without drought stress $(-0.03 \mathrm{MPa})$. The reduction was more pronounced in plants under the severe drought stress $(-0.5 \mathrm{MPa}$ ) (Fig. 1A,B). It should be noted that no significant differences were observed in plant height between the CMG/BR and BRS cultivars in any of the studied water potentials (Fig. $1 A, B$ ).

In a current literature, drought stress is one of the main limiting factors for plant growth. It causes a low pressure potential necessary for the cell enlargement, reducing plant growth and leaf area (Chaitanya et al. 2003, Karthikeyan et al. 2007, Jaleel et al. 2008, Shao et al. 2008). Liu et al. (2003) and Mak et al. (2014) reported that under drought stress, plants reduce growth and leaf area as a response to high water loss through transpiration. It is possible that in the V4 soybean development stage, a greater water loss occurred due to
Giannopolitis and Ries (1977). Samples of plant tissue were added to a $50 \mathrm{mM}$ potassium phosphate buffer ( $\mathrm{pH}$ 7.8), methionine, nitroblue tetrazolium (NBT), EDTA, and riboflavin. A reaction occurred in a box with an irradiance of $15 \mathrm{~W}$ at $25^{\circ} \mathrm{C}$, and enzyme activity was read spectrophotometrically at $560 \mathrm{~nm}$. One unit (U) of SOD corresponds to the amount of SOD that inhibits the photochemical reduction of NBT by $50 \%$.

The CAT activty was determined as described by Nogueirol et al. (2015) in a reaction mixture containing $1 \mathrm{~cm}^{3}$ of a $100 \mathrm{mM}$ potassium phosphate buffer $(\mathrm{pH} 7.5)$ containing $0.025 \mathrm{~cm}^{3}$ of $30 \%(\mathrm{v} / \mathrm{v}) \mathrm{H}_{2} \mathrm{O}_{2}$ solution. The activity was evaluated by spectrophotometry at $25^{\circ} \mathrm{C}$ by monitoring the decomposition of $\mathrm{H}_{2} \mathrm{O}_{2}$ at $240 \mathrm{~nm}$ over $1 \mathrm{~min}$.

The APX activity was measured as described by Gratão et al. (2012) in a reaction consisting of a plant extract, $80 \mathrm{mM}$ potassium phosphate buffer $(\mathrm{pH} 7.0)$, $5 \mathrm{mM}$ ascorbate, $1 \mathrm{mM}$ EDTA, and $1 \mathrm{mM} \mathrm{H}_{2} \mathrm{O}_{2}$. The APX activity was determined by monitoring the rate of ascorbate oxidation at $290 \mathrm{~nm}$ at $30^{\circ} \mathrm{C}$.

The experimental design was arranged in a completely randomized blocks, using six plants per treatment, from three replicate pots with two plants per pot. One plant of each replicate was used for the growth analyzes and the other was used in the laboratory analysis. Each laboratory sample was fragmented into three subsamples, nine samples for each analysis. The statistical analysis was performed using the Tukey test at a 0.05 level of significance.

higher leaf area in comparison to the V2 stage, causing a greater sensitivity to drought stress.

There were significant reductions in stem diameter in MG/BR under the drought stresses $(-0.07$ and $-0.50 \mathrm{MPa})$ in both phenological stages compared to the well-watered control (Fig. 1C,D). The BRS in the V2 stage did not present a reduction in stem diameter, however, at the V4 stage, it exhibited a reduction in stem diameter similarly as MG/BR (Fig. 1D).

No significant difference in plant dry mass was observed between soybean cultivars under well-watered conditions (Fig. 1G,H). However, BRS exhibited a higher response to drought stress when compared to the MG/BR in the V2 stage under the moderate drought stress (Fig. 1G). These results indicate that BRS exhibited a high tolerance to a moderate drought stress when it occurred at the V2 stage.

Certainly, drought stress affects stomatal conductance, and in this case, the reduction was more pronounced during the severe drought stress. However, in the case of stomatal closure, plants do not reduce only water loss through transpiration but also reduce $\mathrm{CO}_{2}$ supply to leaves, and as a consequence, biomass production (Paiva et al. 2005). No differences between cultivars were observed when $\mathrm{g}_{\mathrm{s}}$ was measured at the V2 
stage (Fig. 1E). Contrarily, the data show that during the severe stress, BRS exhibited a higher decrease in stomatal conductance when compared to $\mathrm{MG} / \mathrm{BR}$ at the V4 stage
(Fig. 1F). This characteristic can be related to a greater stomatal closure in the transgenic plants under the drought conditions, thus avoiding excessive water loss.

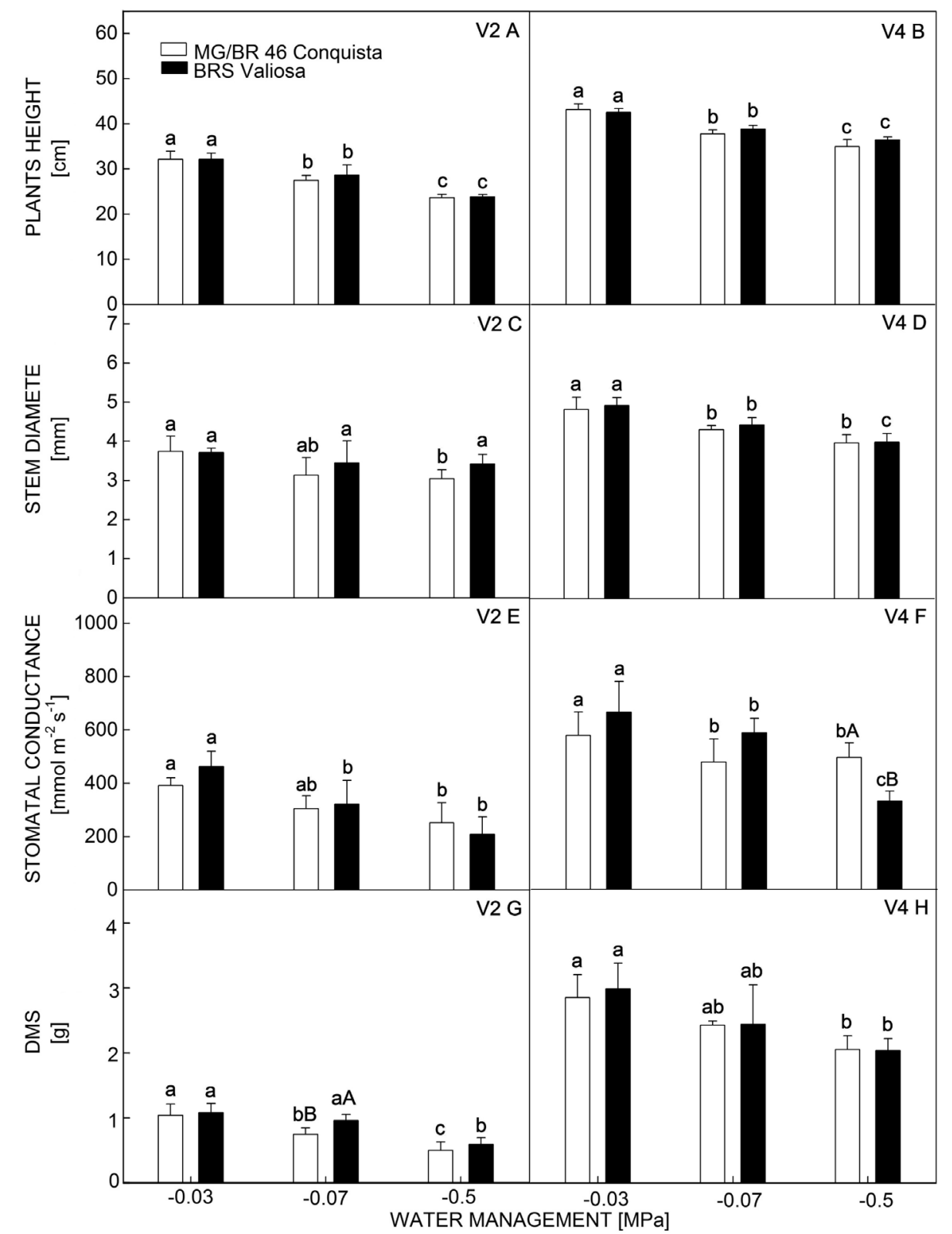

Fig. 1. Effect of drought on plant height $(A-B)$, stem diameter $(C-D)$, stomatal conductance $(E-F)$, and shoot dry mass (DMS; $G$ - $H$ ) in MG/BR 46 Conquista and BRS Valiosa soybean cultivars in the V2 and V4 phenological stages. Means \pm SEs, $n=6$ for plant height, stem diameter, and stomatal conductance and 3 for DMS; means with different lowercase letters differ significantly between water managements and means with different capital letters differ significantly between cultivars (the Tukey test, $P<0.05$ ).

Several studies have reported a progressive reduction in the stomatal conductance of plants under low soil moisture, resulting in a reduction in the net photosynthetic rate and consequently growth (Liu et al. 2005, Ribas-Carbo et al. 2005, Flexas et al. 2006a,b, Afzal et al. 2014, Mak et al. 2014). The net photosynthetic rate under drought stress is reduced mainly due to the closure of stomata (Flexas et al. 2004,
Paiva et al. 2005, Ohashi et al. 2006, Afzal et al. 2014, Mak et al. 2014). Flexas et al. (2006a) reported that under low soil moisture, there is also a reduction in the carbon balance of the plant, which is dependent on the ratio between photosynthesis and respiration.

There are several mechanisms involved in alleviating drought stress. For instance, plants can accumulate proline, a compatible osmolyte (Mwadzingeni et al. 
2016). It is worth noting that there was a possible correlation between the increase in proline content and progressive drought stress (Fig. 2) in both the cultivars. The same pattern was observed in sugarcane (Queiroz et al. 2011) and maize (Anjum et al. 2016). Nonetheless, $\mathrm{MG} / \mathrm{BR}$ exhibited a higher proline content when compared to BRS at $-0.5 \mathrm{MPa}$ (Fig. 2). Proline can contribute to the stabilization of membranes and subcellular structures and can scavenge ROS (Kaur and Asthir 2015). Although $\mathrm{MG} / \mathrm{BR}$ exhibited a higher proline content at $-0.5 \mathrm{MPa}$ (Fig. 2), it exhibited a higher MDA content at the V4 phenological stage when compared to BRS, which suggests that proline accumulation did not avoid damages to the membrane in MG/BR (Fig. 3B).

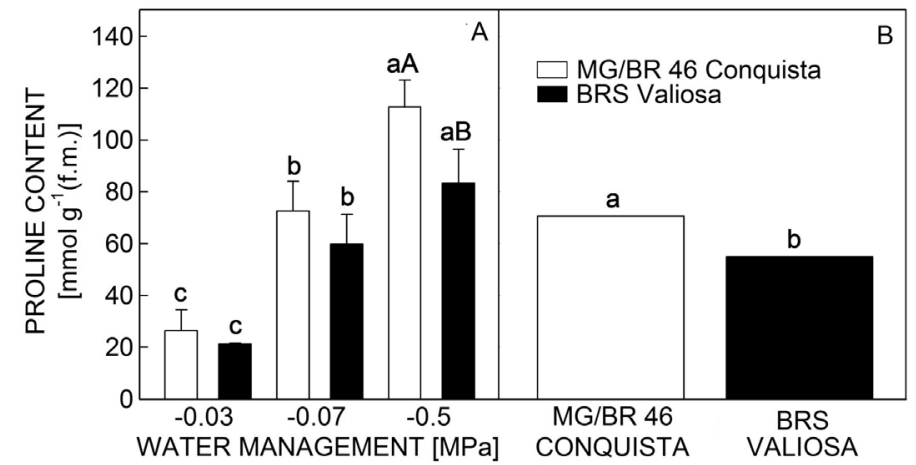

Fig. 2. Effect of drought on proline content in soybean cultivars MG/BR 46 Conquista and BRS Valiosa in the V4 phenological stage $(A)$ and average proline content between these cultivars $(B)$. Means \pm SEs, $n=9$, means with different lowercase letters differ significantly between water managements, and means with different capital letters differ significantly between cultivars (the Tukey test, $P<0.05)$.

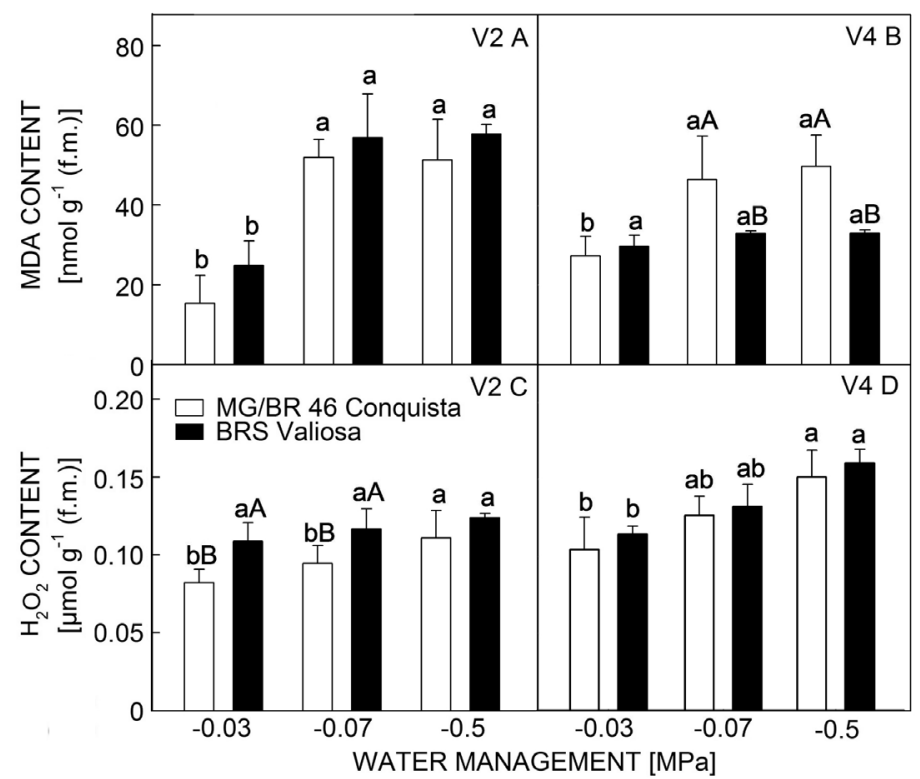

Fig. 3. Effect of drought on malondialdehyde (MDA) content $(A, \mathrm{~B})$ and $\mathrm{H}_{2} \mathrm{O}_{2}$ content $(C, D)$ in soybean cultivars $\mathrm{MG} / \mathrm{BR} 46$ Conquista and BRS Valiosa in the V2 and V4 phenological stages. Means \pm SEs, $n=9$, means with different lowercase letters differ significantly between water managements, and means with different capital letters differ significantly between cultivars (the Tukey test, $P<0.05)$.

Antioxidant enzymes allow plants to avoid or tolerate oxidative stress triggered by drought stress (Farooq et al. 2009, Silva et al. 2016). We selected the key antioxidant enzymes SOD, APX, and CAT based on numerous reports regarding their responses to drought stress in plants. The SOD is in the first line of defense as it converts $\mathrm{O}_{2}^{-}$into $\mathrm{H}_{2} \mathrm{O}_{2}$. It is induced in a number of plant species when exposed to drought stress (Darmanti et al.
2016, Khakdan et al. 2016). The MG/BR exhibited a higher SOD activity when compared with BRS at $-0.5 \mathrm{MPa}$ during the V2 phenological stage (Fig. $4 A$ ). Nonetheless, both the cultivars exhibited similar $\mathrm{H}_{2} \mathrm{O}_{2}$ productions (Fig. $3 C$ ). In the V4 stage, although $\mathrm{H}_{2} \mathrm{O}_{2}$ production was not progressive (Fig. $3 D$ ), it was clearly noted that the transgenic plants maintained SOD activity in progressive drought stress (Fig. 4B), which reduced 
toxic levels of $\mathrm{O}_{2}^{-}$, thus avoiding tissue damage.

Hydrogen peroxide produced in response to SOD activity and other metabolic processes can subsequently be reduced to $\mathrm{H}_{2} \mathrm{O}$ by the actions of CAT and APX. Our results indicate that $\mathrm{CAT}$ activity was stable during progressive drought but varied among phenological stages and cultivars (Fig. 4C,D). The MG/BR exhibited a higher CAT activity than BRS in the V2 phenological stage but lower in the V4 stage. Activity of APX was also higher in MG/BR 46 than in BRS in the V2 stage (Fig. 5E), which contributed to a decrease in $\mathrm{H}_{2} \mathrm{O}_{2}$ content (Fig. 3C). On the other hand, BRS exhibited a pronounced increase in APX activity during the V4 stage (Fig. $4 F$ ), which indicates a late ameliorative response.

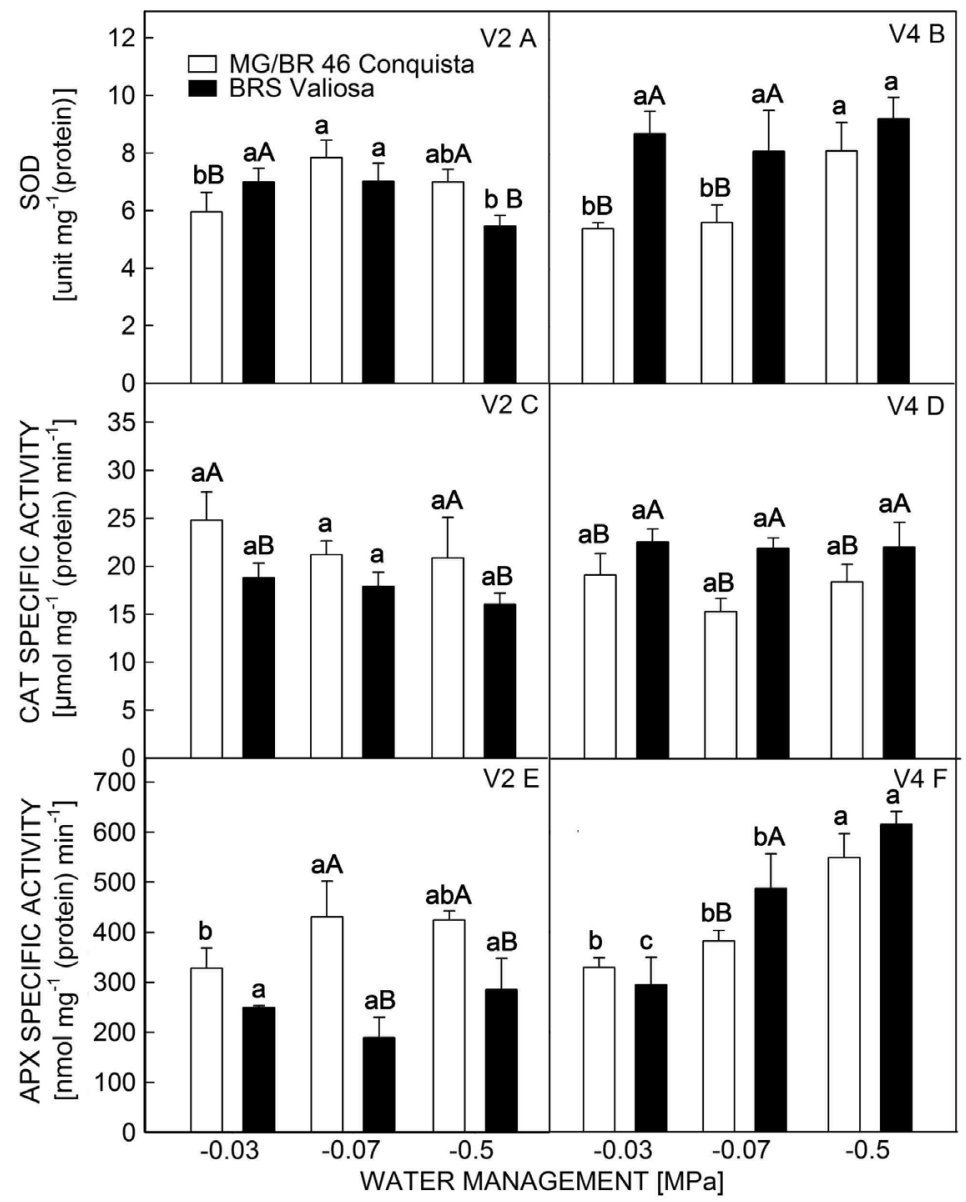

Fig. 4. Effect of drought on activity of $\operatorname{SOD}(A, B)$, catalase specific activity $(C, D)$, and APX specific activity $(E, F)$ in soybean cultivars MG/BR 46 Conquista and BRS Valiosa in the V2 and V4 phenological stages. Means \pm SEs, $n=9$, means with different lowercase letters differ significantly between water managements, and means with different capital letters differ significantly between cultivars (the Tukey test, $P<0.05$ ).

Correlation between antioxidants and ROS production determines the tolerance or susceptibility of a genotype to drought stress (Mittler et al. 2002). Both the soybean cultivars exhibited a slight increase in some of antioxidant enzyme activities. Nonetheless, BRS demonstrated an improved antioxidant enzyme activity when compared with MG/BR during the V4 stage (Fig. 4), which contributed to membrane stability measured via MDA content (Fig. 3B). On the other hand, MDA content was higher in both the cultivars at the V2 stage (Fig. $3 A$ ) and exhibited an intense decrease in the V4 stage (Fig. $3 B$ ). These data suggest that both the soybeans cultivars can partially tolerate drought stress in the first period of development. Nonetheless, BRS exhibited a continued capability to control ROS production and scavenging, which may overcome the stress imposed by a long period of drought.

Several specific sets of genes that are unique to transgenic plants can be activated (Abdeen and Miki 2009), but different responses are observed depending on interactions with respective environment (Darmency 2013). Furthermore, drought stress tolerance involves several mechanisms, which include molecular, anatomic, and metabolic responses (Makbul et al. 2011, Kidokoro et al. 2015, Yu et al. 2016, Gonçalves et al. 2017). Our results indicate that antioxidant defense mechanisms were correlated with the differences between stress tolerance in non-transgenic and transgenic cultivars. 


\section{Conclusion}

Drought is a limiting factor to crop production. The physiologic and biochemical parameters analyzed in this study allowed us to suggest that the BRS cultivar overcame the stress imposed by the drought for a long period. Although both the cultivars were able to tolerate progressive drought stress, we observed that the BRS
Valiosa exhibited a higher enzyme activities, allowing better control of oxidative stress and better development of plants under water stress. Our results showed that the plant antioxidant system contributes to increasing drought stress tolerance and could be used in the selection of plants better adapted to stress conditions.

\section{References}

Abdeen, A., Miki, B.: The pleiotropic effects of the bar gene and glufosinate on the Arabidopsis transcriptome. - Plant biotechnol. J. 7: 266-282, 2009.

Afzal, A., Gulzar, I., Shahbaz, M., Ashraf, M.: Water deficitinduced regulation of growth, gas exchange, chlorophyll fluorescence, inorganic nutrient accumulation and antioxidative defense mechanism in mungbean [Vigna radiata (L.) Wilczek]. - J. appl. Bot. Food Qual. 87: 147156, 2014.

Ahmad, P., Jaleel, C.A., Sharma, S.: Antioxidant defense system, lipid peroxidation, proline-metabolizing enzymes, and biochemical activities in two Morus alba genotypes subjected to $\mathrm{NaCl}$ stress. - Russ. J. Plant Physiol. 57: 509517, 2010.

Alexieva, V., Sergiev, I., Mapelli, S., Karanov, E.: The effect of drought and ultraviolet radiation on growth and stress markers in pea and wheat. - Plant Cell Environ. 24: 13371344, 2001.

Alves, L.R., Monteiro, C.C., Carvalho, R.F., Cury, P.R., Tezotto, T., Azevedo, R.A., Gratão, P.L.: Cadmium stress related to root-to-shoot communication depends on ethylene and auxin in tomato plants. - Environ. exp. Bot. 134: 102115, 2017.

Anjum, S.A., Tanveer, M., Ashraf, U., Hussain, S., Shahzad, B., Khan, I., Wang. L.: Effect of progressive drought stress on growth, leaf gas exchange, and antioxidant production in two maize cultivars. - Environ. Sci. Pollut. Res. 23: 1713217141, 2016.

Ashraf, M.: Inducing drought tolerance in plants: recent advances. - Biotechnol. Adv. 28: 169-183, 2010.

Ashraf, M., Harris, P.J.C.: Photosynthesis under stressful environments: an overview. - .Photosynthetica. 51: 163-190, 2013.

Balardin, R.S., Silva, F.D., Debona, D., Corte, G.D., Favera, D.D., Tormen, N.R.: Seed treatment with fungicides and insecticides reducing the hydric stress on soybean plants. Ciênc. rural. 41: 1120-1126, 2011.

Bates, L.S., Waldren, R.P., Teare, I.D.: Rapid determination of free proline for water-stress studies. - Plant Soil 39: 205207, 1973.

Boaretto, L.F., Carvalho, G., Borgo, L., Creste, S., Landell, M.G.A., Mazzafera. P., Azevedo, R.A.: Water stress reveals differential antioxidant responses of tolerant and nontolerant sugarcane genotypes. - Plant Physiol. Biochem. 74: 165-175, 2014.

Bradford, M.M.: A rapid and sensitive method for the quantitation of microgram quantities of protein utilizing the principle of protein-dye binding. - Anal. Biochem. 72: 248254, 1976.

Cabuslay, G.S., Ito, O., Alejar, A.A.: Physiological evaluation of responses of rice (Oryza sativa L.) to water deficit. Plant Sci. 163: 815-827, 2002.
Chaitanya, K.V., Jutur, P.P., Sundar, D., Reddy, A.R.: Water stress effects on photosynthesis in different mulberry cultivars. - Plant Growth Regul. 40: 75-80, 2003.

Choudhury, F.K., Rivero, R.M., Blumwald, E., Mittler, R.: Reactive oxygen species, abiotic stress and stress combination. - Plant J. 90: 856-867, 2017.

Darmency, H.: Pleiotropic effects of herbicide-resistance genes on crop yield: a review. - Pest Manage. Sci. 69: 897-904, 2013.

Darmanti, S., Santosa., Dewi, K., Nugroho, L.H.: Antioxidative defenses of soybean [Glycine max (L.) Merr. cv. Grobogan] against purple nutsedge (Cyperus rotundus L.) interference during drought stress. - J. Anim. Plant Sci. 26: 225-232, 2016.

Demidchik, V.: Mechanisms of oxidative stress in plants: from classical chemistry to cell biology. - Environ. exp. Bot. 109: 212-228, 2015.

Demirtas, Ç., Yazgan, S., Candogan, B.N., Sincik, M., Büyükcangaz, H., Göksoy, A.T.: Quality and yield response of soybean (Glycine max L. Merrill) to drought stress in sub-humid environment. - Afr. .J Biotechnol. 9: 6873-6881, 2010.

Fang, Y., Xiong, L.: General mechanisms of drought response and their application in drought resistance improvement in plants. - Cell. mol. Life Sci. 72: 673-689, 2015.

Farooq, M., Wahid, A., Kobayashi, N., Fujita, D., Basra, S.M.A.: Plant drought stress: effects, mechanisms and management. - Agron. Sustain. Dev. 29: 153-188, 2009.

Fehr, W.R., Caviness, C.E. (ed.): Stages of Soybean Development. - State University of Science and Technology, Ames 1977.

Flexas, J., Bota, J., Loreto, F., Cornic, G., Sharkey, T.D.: Diffusive and metabolic limitations to photosynthesis under drought and salinity in $C_{3}$ plants. - Plant Biol. 6: 269-279, 2004.

Flexas, J., Bota, J., Galmés, J., Medrano, H., Ribas-Carbó, M.: Keeping a positive carbon balance under adverse conditions: responses of photosynthesis and respiration to water stress. - Physiol Plant. 127: 343-352, 2006a.

Flexas, J., Ribas-Carbó, M., Bota, J., Galmés, J., Henkle, M., Martínez-Cañellas, S., Medrano, H.: Decreased Rubisco activity during water stress is not induced by decreased relative water content but related to conditions of low stomatal conductance and chloroplast $\mathrm{CO}_{2}$ concentration. New Phytol. 172: 73-82, 2006b.

Giannopolitis, C.N., Ries, S.K.: Superoxide dismutases I. Occurrence in higher plants. - Plant Physiol. 59: 309-314, 1977.

Gonçalves, C.G., Silva Junior, A.C., Pereira, M.R.R., Gasparino, E.C., Martins, D.: Morphological modifications in soybean in response to soil water management. - Plant Growth Regul. 83: 105-117, 2017. 
Gratão, P.L., Monteiro, C.C., Carvalho, R.F., Tezotto, T., Piotto, F.A., Peres, L.E.P., Azevedo, R.A.: Biochemical dissection of diageotropica and Never ripe tomato mutants to Cd-stressful conditions. - Plant Physiol Biochem. 56: 7996, 2012.

Heath, R.L., Packer, L.: Photoperoxidation in isolated chloroplasts: I. Kinetics and stoichiometry of fatty acid peroxidation. - Arch. Biochem. Biophys. 125: 189-198, 1968.

Hippler, F.W.R., Boaretto, R.M., Quaggio, J.A., Azevedo, R.A., Mattos, D., Jr.: Towards soil management with $\mathrm{Zn}$ and Mn: estimates of fertilisation efficacy of Citrus trees. - Ann. appl. Biol. 166: 484-495, 2015.

$\mathrm{Hu}$, H., Xiong, L.: Genetic engineering and breeding of drought-resistant crops. - Annu. Rev. Plant Biol. 65: 715$741,2014$.

Jaleel, C.A., Manivannan, P., Lakshmanan, G.M.A., Gomathinayagam, M., Panneerselvam, R.: Alterations in morphological parameters and photosynthetic pigment responses of Catharanthus roseus under soil water deficits. - Colloids Surf. B: Biointerfaces 61: 298-303, 2008.

Juenger, T.E.: Natural variation and genetic constraints on drought tolerance. - Curr. Opin. Plant Biol. 16: 274-281, 2013.

Karthikeyan, B., Jaleel, C.A., Gopi, R., Deiveekasundaram, M.: Alterations in seedling vigour and antioxidant enzyme activities in Catharanthus roseus under seed priming with native diazotrophs. - J. Zhejiang Univ. Sci. B. 8: 453-457, 2007.

Kaur, G., Asthir, B.: Proline: a key player in plant abiotic stress tolerance. - Biol Plant. 59: 609-619, 2015.

Khakdan, F., Ranjbar, M., Nasiri, J., Ahmadi, F.S., Bagheri, A., Alizadeh, H.: The relationship between antioxidant compounds contents and antioxidant enzymes under waterdeficit stress in the three Iranian cultivars of basil (Ocimum basilicum L.). - Acta Physiol Plant. 38: 226, 2016.

Klar, A.E., Villa Nova, N.A., Marcos, Z.Z., Cervellini, A.: Determination of soil moisture by weighing method. - An. Esc. Super. Agr. 23: 15-30, 1966.

Klar, A.E. (ed.): Evapotranspiração. [Evapotranspitation.]. Nobel, São Paulo 1984. [In Portug.]

Kidokoro, S., Watanabe, K., Ohori, T., Moriwaki, T., Maruyama, K., Mizoi, J., Htwe, N.M.P.S., Fujita, Y., Sekita, S., Shinozaki, K., Yamaguchi-Shinozaki, K.: Soybean DREB1/CBF-type transcription factors function in heat and drought as well as cold stress-responsive gene expression. - Plant J. 81: 505-518, 2015.

Li, W., Wang, T., Zhang, Y., Li, Y.: Overexpression of soybean miR172c confers tolerance to water deficit and salt stress, but increases ABA sensitivity in transgenic Arabidopsis thaliana. - J. Exp. Bot. 67: 175-194, 2016.

Liu, F., Jensen, C.R., Andersen, M.N.: Hydraulic and chemical signals in the control of leaf expansion and stomatal conductance in soybean exposed to drought stress. - Funct. Plant Biol. 30: 65-73, 2003.

Liu, F., Andersen, M.N., Jacobsen, S.E., Jensen, C.R.: Stomatal control and water use efficiency of soybean (Glycine max L. Merr.) during progressive soil drying. - Environ. exp. Bot. 54: 33-40, 2005 .

Madani, A., Nehal, M., Haque, S.S., Khan, A.: Perspective of oxidative stress in a biological system and prevention by naturally occurring antioxidant. - Proc. nat. Acad Sci., India, Sect B Biol. Sci. 80: 287-295, 2010.

Makbul, S., Güler, N., Durmuş, N.S., Güven, S.: Changes in anatomical and physiological parameters of soybean under drought stress. - Turk. J. Biol. 35: 369-377, 2011.

Mak, M., Babla, M., Xu, S.C., O'Carrigan, A., Liu, X.H., Gong, Y.M., Holford, P., Chen, Z.H.: Leaf mesophyll $\mathrm{K}^{+}, \mathrm{H}^{+}$and $\mathrm{Ca}^{2+}$ fluxes are involved in drought-induced decrease in photosynthesis and stomatal closure in soybean. - Environ. exp Bot. 98: 1-12, 2014.

Martinez, V., Mestre, T.C., Rubio, F., Girones-Vilaplana, A., Moreno, D.A., Mittler, R., Rivero, R.M.: Accumulation of flavonols over hydroxycinnamic acids favors oxidative damage protection under abiotic stress. - Front. Plant Sci. 7: 1-17, 2016.

Meckel, L., Egli, D.B., Phillips, R.E., Radcliffe, D., Leggett, J.E.: Effect of moisture stress on seed growth in soybeans. Agron. J. 76: 647-650, 1984.

Mittler, R.: Oxidative stress, antioxidants and stress tolerance. Trends Plant Sci. 7: 405-410, 2002.

Mwadzingeni, L., Shimelis, H., Tesfay, S., Tsilo, T.J.: Screening of bread wheat genotypes for drought tolerance using phenotypic and proline analyses. - Front. Plant Sci. 7: $1-12,2016$.

Nogueirol, R.C., Monteiro, F.A., Gratão, P.L., Borgo, L., Azevedo, R.A.: Tropical soils with high aluminum concentrations cause oxidative stress in two tomato genotypes. - Environ. Monit. Assess. 187: 1-16, 2015.

Ohashi, Y., Nakayama, N., Saneoka, H., Fujita, K.: Effects of drought stress on photosynthetic gas exchange, chlorophyll fluorescence and stem diameter of soybean plants. - Biol Plant. 50: 138-141, 2006.

Paiva, A.S., Fernandes, E.J., Rodrigues, T.J., Turco, J.E.: Stomatal conductance in leaves of bean plants submitted to different irrigation regimes. - Eng. Agr. 25: 161-169, 2005.

Queiroz, R.J.B., Santos, D.M.M.D., Ferraudo, A.S., Carlin, S.D., Silva, M.D.A.: Biochemical and physiological responses of sugarcane cultivars to soil water deficiencies. Sci. Agr. 68: 469-476, 2011.

Ribas-Carbo, M., Taylor, N.L., Giles, L., Busquets, S., Finnegan, P.M., Day, D.A., Lambers, H., Medrano, H., Berry, J.A., Flexas, J.: Effects of water stress on respiration in soybean leaves. - Plant Physiol. 139: 466-473, 2005.

Sarkar, K.K., Mannan, M.A., Haque, M.M., Ahmed, J.U.: Physiological basis of water stress tolerance in soybean. Bangladesh Agron. J. 18: 71-78, 2015.

Shao, H.B., Chu, L.Y., Shao, M.A., Jaleel, C.A., Hong-Mei, M.: Higher plant antioxidants and redox signaling under environmental stresses.- Compt. Rend. Biol. 331: 433-441, 2008.

Sharma, P., Jha, A.B., Dubey, R.S., Pessarakli, M.: Reactive oxygen species, oxidative damage, and antioxidative defense mechanism in plants under stressful conditions. - J. Bot. 2012: 1-26, 2012.

Silva, A.R.A., Bezerra, F.M.L., Lacerda, C.F., Pereira Filho, J.V., Freitas, C.A.S.: Gas exchange in sunflower plants subjected to water deficit at different stages of growth. Rev. Ciênc. Agron. 44: 86-93, 2013.

Silva, P.A., Oliveira, I.V., Rodrigues, K.C.B., Cosme, V.S., Bastos, A.J.R., Detmann, K.S.C., Cunha, R.L., FestucciBuselli, R.A., Damatta, F.M., Pinheiro, H.A.: Leaf gas exchange and multiple enzymatic and non-enzymatic antioxidant strategies related to drought tolerance in two oil palm hybrids. - Trees 30: 203-214, 2016.

Tsumanuma, G.M., Carvalho, S.J.P., Fancelli, A.L., Bernardes, M.S., Rodrigues, M.A.T., Begliomini, E.: Effects of herbicide and fungicide applications on the growth of two soybean cultivars. - Rev. Ceres. 57: 742-750, 2010.

Xing, X., Zhou, Q., Xing, H., Jiang, H., Wang, S.: Early 
Abscisic acid accumulation regulates ascorbate and glutathione metabolism in soybean leaves under progressive water stress. - J. Plant Growth Regul. 35: 865-876, 2016.

Yang, P.H., Li, G.Q., Guo, L., Wu, S.J.: Effect of drought stress on plasma membrane permeability of soybean varieties during flowering-podingstage. - Agr. Res. arid Areas 21:
$127-130,2003$

Yu, X., James, A.T., Yang, A., Jones, A., Mendoza-Porras, O., Bétrix, C.A., Ma, H., Colgrave, M.L.: A comparative proteomic study of drought-tolerant and drought-sensitive soybean seedlings under drought stress. - Crop Pasture Sci. 67: 528-540, 2016. 